\title{
Researching the Impact of the Economic Crisis on Student Life in Greece
}

\author{
Maria Kouroutsidou, Nikolaos Raptis and Konstantinos Karampelas \\ University of the Aegean, Rhodes, Greece \\ http:/ / orcid.org/0000-0002-0345-541X \\ http://orcid.org/0000-0001-7781-5556 \\ http://orcid.org/0000-0001-6631-1408
}

\begin{abstract}
The present work explores the views of students in Greek Universities who have been impacted by the economic crisis in Greece since 2009. In the theoretical part, the economic crisis is considered a violent change that tends to be incorporated permanently into socioeconomic life, affecting public expenditure in tertiary education as well as family income and expenditure. These developments harm university studies, student life, and expectations of graduates for their future. The theoretical part ends with the formulation of three research axes about the extent to which the economic crisis affects (a) the socio-economic environment and family spending, (b) students' life at the university, and (c) students' perception of their future. In the empirical part, a series of questions along these axes are investigated quantitatively, through descriptive statistics using a questionnaire specially constructed for this research, which addressed to students. The sample comprised 300 university students. Their views seem to primarily support the hypothesis of the negative impacts of the economic crisis on families, studies, and expectations. The study ends with suggestions for further research.
\end{abstract}

Keywords: Economic Crisis; Student Life; University; Greece

\section{Nature and scope of the Problem: An introduction}

The present research examines the crisis that Greece has been experiencing since 2009 and its impact on universities, as perceived by the students, in terms of the impact on their background, studying conditions, and prospects. This crisis influenced various aspects of life and public services in Greece, including education (Azaria et al., 2020).

Universities worldwide have suffered enormously from the crisis of the first decade of the 21st century (Coleman \& Bekhradnia, 2014; Daim \& Ozdemir, 2015). Altundemir (2012), when investigating the impact of that crisis on American public universities, concluded that several states had taken drastic measures to reduce spending in the universities to face the challenging economic climate. In 
various states and for various institutions, the reduction was affected in different ways. In some states, funding to higher education institutions was reduced in general, and in other cases, funding for expenditure on redundant personnel was reduced. Due to these reduction measures, some universities have increased tuition fees. Other states have reduced funding or scholarship opportunities for students and have even terminated programs. To ensure the effective functioning of their universities in the future, the boards of directors of many universities have begun to form research policies that will ensure the institution's long-term goals. The literature reveals that these measures create a dilemma about whether to opt for university education.

However, despite the economic crisis, enrollment at American universities has not declined, probably because of the widely held belief that university education is essential. Especially in these challenging times, it seems that higher education qualification is worth purchasing at all costs, even though it poses many challenges for students. This finding broadly aligns with the theory of human capital and the importance attributed to education generally and higher education, particularly by individuals and societies (Becker, 1993).

The European Universities Association (EUA, 2011) investigated the impact of this crisis on public universities in various European countries and reached similar conclusions. Initially, as the State funds a large proportion of European universities, many national governments that decided to take strict austerity measures reduced the average funding of higher education to decrease public expenditure. Many universities were compelled to make drastic reforms, as teaching budgets were reduced, and faculties or departments merged while research activity was generally reduced. However, several countries either increased or did not reduce the funding for research, probably because it is widely believed that universities through research can help to deal with the crisis and provide a stimulus for economic growth and social welfare. Such a stimulus would come by way of promoting new fields of study and the creation of new job opportunities (Christopherson et al., 2014). Several universities have considered private funding and raising tuition fees as options.

Nevertheless, even in Europe, the number of students who want to pursue university studies has increased, which is now mentioned as a rising challenge. In any case, it increases the validity of the finding that people consider a university degree as an essential qualification and a crisis does not impede them from obtaining it (EUA, 2011).

In short, higher education has been affected by the crisis in various parts of the world. However, the idea that university studies are necessary and worthwhile did not seem to become less popular (EUA, 2011; Christopherson et al., 2014; Coleman \& Bekhradnia, 2014). This trend is justified to exist in the Greek context (Katsikas, 2013). However, limited research emphasizes students' opinions, which is the main point of this particular study. 


\section{Review of the Relevant Literature}

As the article emphasizes the impact of the crisis on higher education, as perceived by students, in a particular context, which is Greece, it is crucial to go through literature review findings around the fields of study that this study addresses, in order to form the appropriate hypothesis or assertion. They concern research on higher education trends, the role of students in higher education, the socio-economic crisis as it occurred in Greece, generally and specifically in what concerns higher education (EUA, 2011; Cohen et al, 2013; Katsikas, 2013).

\section{Trends in Higher Education}

Since the 1950s, sociological and economic research is being conducted on the role of education and its correlation with development.

At an individual level, through an economic and social perspective, the theory of human capital (Becker, 1993) supports the notion that education is an investment that qualifies people to be productive and therefore provides better access to the labor market and higher income in professional life. At the same theoretical level, higher education has been considered a useful tool not only for the development of personal skills and attainment of knowledge and abilities by the people but also for the promotion of innovative ways of thinking, preparation for mobility across the world, and establishment of scientific and professional identity. All these can lead to a better quality of life (Oxford University, 2015). Simultaneously, many theorists have supported that education, when established as an institution with the vision to reduce social inequalities, can increase social mobility for underprivileged people of low social classes through the appropriate use of knowledge, skills, and capacities (Becker, 1993).

Through economic and social perspectives, the influence of higher education on productivity is considered to lead to increased GDP and thus to a high economic and social development, reducing poverty, improving quality of life, and prefectural development (Oxford University, 2015).

This relationship between education, improvement of individual career prospects, and socio-economic development has been a fertile field for research (Wolf, 2002). Though this view has been criticized, many countries have opted to invest in the expansion of higher education by founding new universities, schools, and departments in universities. According to Berry (2002), the governments' approach has been supported by people of every background who believe university education is the key to future success. Aside from this, it is widely believed that higher education is an essential condition for adapting to reforms and changes in a flexible labor market and improving and updating the knowledge and skills of workers. For these reasons, Coleman and Bekhradnia (2014) state that a lack of university education opens fewer opportunities for professional development and career.

As Altbach et al. (2009) mention, the significant trends in higher education nowadays are affected by a crucial challenge. This is because governments link the financing of universities with social and political topics they view as relevant. 
Eight basic dimensions or trends influence any policy concerning higher education.

The first has to do with the orientation toward knowledge-based economies. Higher education has a crucial role in that orientation because, in such economies, college or university education is seen to be useful both at personal and social levels by individuals. They see a university qualification as vital because they see educated individuals engaged in research and progress as more likely to achieve.

The second trend is relevant to the first and relates to the familial expectations that individuals should have higher educational qualifications. Even though the rising number of university graduates caused by this expectation sometimes cannot be absorbed by the labor market, this trend has not stopped. Contrarily, it has triggered a demand for further higher education at certificate, undergraduate, and post-graduate levels, which is seen as an edge in a highly competitive labor market (Altbach et al., 2009; Berry, 2002).

The third trend that arises from the previous trend is the rising cost of studies per student. The growing number of students attending universities indicates a growth in the demand for higher education. Consequently, to make up for the lack of government funding, higher education institutions raise the cost of education.

The fourth trend arises from the inability of governments to meet the rising demand for higher education. In other words, the governments are neither flexible nor competent enough to meet the demand for funds made by the universities to cope with the increasing expenses caused by the rising number of students. This trend, combined with the demands for and rising costs of other services, causes the governments to raise tax rates and look for cost-effective services (Altbach et al., 2009; Altundemir, 2012).

The fifth trend is globalization, a multi-dimensional and highly complex phenomenon. Therefore, its influence on universities is multi-dimensional and complex. For example, due to globalization, people can now move with greater ease from one country to another than in the past. Therefore, more people than earlier migrate to other countries for education, increasing enrollment at universities. Moreover, globalization permits industries to move from one country to another for advantages such as a lower cost of education, which causes changes in government revenue and expenditure, including expenses on higher education.

The sixth trend is the orientation of universities toward tapping new financial resources. This trend may be motivated or guided by governmental policies. As government expenditure and funds in higher education decline, universities seek new sources of funds. One of the sources is to raise tuition fees. This inevitably causes social debates and some dissatisfaction (Altbach et al., 2009; Christopherson et al., 2014; Hasanen, 2020).

The seventh trend comprises the growing emphasis on the finance and funding factor. As universities have to develop policies and solutions to support their 
function, they now pay considerable attention to finding sources for funds than earlier. Moreover, they search for greater cost-effective solutions to carry on their functions.

The eighth and final trend is the tendency of the universities to become more autonomous and competitive. Many national governments, to help higher education survive the fierce competition, decide to liberate the universities' management to raise funds. In other words, universities are expected to cope with new realities of rules of the free market. In many cases, governments promote private funding or private colleges or universities.

Overall, due to these trends, there is concern about the impact of this external competitive climate on the universities (Altbach et al., 2009; Coleman \& Bekhradnia, 2014; Sointu et al., 2019). Several solutions have been suggested and adopted as part of the policy of cost-cutting, of which some are promoted by central authorities or universities and other institutions and implemented with varied effects. Many universities have restructured themselves and their functions by introducing new courses or new and less expensive modes of teaching, such as online classes. Several universities have revised pay structures for their employees. Furthermore, there is a significant reduction in student support by the State and other organizations that provide student loans (Altbach et al., 2009).

\section{The Role of Students}

Overall, students have been the center of attention for central policymaking currents that arise due to more full social forces and phenomena such as globalization, immigration, cultural exchanges, and increasing diversity of societies. The policy focuses on how to help students support themselves financially rather than funding. Though the students' dominant role in society's future progress is recognized, they face significant challenges (Altbach et al., 2009; Martin \& Sauvageot, 2011; UNESCO, 2009).

The role of students and their attitudes toward university studies can be approached in three categories along three axes. The first axis concerns their families and social background and how they affect their plans and decisions for studies. University policies worldwide indirectly expect students to find the means to finance their studies. Students and their families are expected to decide how to meet this financial challenge. The decisions might focus on setting priorities, prioritizing the family's basic needs and expenses, and ranking the priority of higher education among all the needs. In other words, students and their families should review their needs and finances and decide what they can sacrifice to spare the money to finance the higher education of their younger members. While deciding, they will probably need to develop a plan and focus on what the family may gain from their children's higher education. The younger members need to assess what they will do with their university degree and where and what sort of work they seek. At this stage, they will have to assess the general climate and conditions of society, especially the labor market and the opportunities it offers. Usually, during a crisis, students and families plan differently than during prosperity. In the former, they are more concerned about 
how to minimize the cost of gaining the desired degree to provide a sustainable career (Christopherson et al., 2014; Martin \& Sauvageot, 2011; UNESCO, 2009).

The second dimension is that of the impact of the economic crisis on students' life. Students' attitudes, which positively influence their decisions, are affected by the general trends in education and universities. Overall, students will experience the outcomes of governmental decisions on higher education and, similarly, might have to be resigned to the side-effects of the challenges arising out of these policies. These outcomes and challenges might generally be linked to financial factors or decisions. For example, students will probably notice when the government reduces investment in higher education. It would have several consequences, such as fewer resources for the universities; fewer university employees of every category, such as academic, teaching, research and administration; fewer funding opportunities for students; reduced campus activities of every kind; an overall pessimist attitude. However, the impact of the crisis might not be felt in the universities alone. The family and background of the student might be affected as well. This would probably also influence students' decisions and attitudes. For example, while searching for cost-effective studies, young people might opt not to relocate but may prefer studying in their hometown to save accommodation expenses. Furthermore, they may economize on expenses such as clothing and even writing material. If moving to the university town is unavoidable, students may work or move into shared accommodation to save expenses. In any case, any student desiring higher education must balance the impact of the crisis through several decisions related to their studies (Altbach et al., 2009; Martin \& Sauvageot, 2011; UNESCO, 2009; Benham et al., 2020).

The third dimension specifically concerns students' expectations and how they are affected by the crisis. Students' expectations are certainly a complicated topic, highly influenced by social factors and economic motivations. They might concern future career opportunities in general and the relationship between qualifications and job and career. Moreover, they may focus on how social factors correctly interact and interrelate with their decisions, either at a personal level or at the level of the larger student population. For example, students during a challenging period might decide not to opt for studying the subject that interests them most because the one they choose provides more opportunities for work and good quality of life - the two desires motivate young people to relocate (Altbach et al., 2009; Martin \& Sauvageot, 2011).

The three dimensions of the crisis that impact students' background, life, and expectations are closely interwoven. Various aspects of each dimension sometimes merge into the others. However, they provide a clear outline of how the crisis and the more extensive community influence students' experience and attitudes toward universities, higher education, studies, degrees, and career paths. Literature and research approached them in a piecemeal and scattered way without focusing on students (Christopherson et al., 2014; Martin \& Sauvageot, 2011; UNESCO, 2009). The central topic of investigation in this research is this neglected area. It is at that point the rationale for this study is located. 


\section{Education and Socio-Economic Environment in Greek Society}

In Greece, according to Petmezidou-Tsoulouvi (1987), Kazamias et al. (2002), and Sianou-Kyrgiou (2010), significant research concerned the development and social status of higher education. Due to higher education, a rising number of persons were finding access to more and better work opportunities and social mobility had increased.

Despite the observed concerns over the potential of higher education to assist social mobility, Greek families have always supported their children to pursue higher education leading to a degree (Fragoudaki, 1985; Sianou-Kyrgiou, 2010). This entails much investment of time and money in private afternoon courses to prepare the children for highly competitive entrance exams to universities to enter prestigious schools or departments that are expected to lead to a high quality of life and high social, professional, and financial status in future. Moreover, the Greek State emphasizes higher education and its development (Pesmatzoglou, 1989; Katsikas, 2013). As it was concluded by the research carried out by the Greek Foundation of Economic and Industrial Research IOVE, (2017) especially after the 1997 reforms, higher education departments and universities were expanded and new universities were established at the prefectural level to give young people broader access to higher education by steeply increasing the number of places in Greek universities. However, this reform has caused debate over the quality and outcomes of higher education. Nevertheless, this did not change the status of Greek universities from being selective to selected. Competition for a place in Greek universities remained severe, particularly in prestigious schools and courses likely to guarantee excellent career opportunities (Gouvias, 2012; Azaria et al., 2020).

In short, international trends around higher education have also been observed in Greek society. The number of students willing to attend universities has been rising. The reason is the broader belief that a university degree can lead to better career opportunities and quality of life. Families encourage this belief in young people and students (Altbach et al., 2009). Universities and the national government had to cope with this rising demand and challenges accompanying the increasing costs (Christopherson et al., 2014).

\section{Hypothesis}

In Greece, since the economic crisis of 2009 broke out, all aspects of economic and social life have been significantly affected (Chrysochoou et al., 2013; Sklavos, 2014). Austerity measures, high taxation, falling income, rising unemployment, and drastic reforms have been a reality. This reality is expected to stimulate further reforms in education (Fullan, 2001), which is expected to impact educational institutions, including the institutions of higher education, systems, and structures (Sklavos, 2014).

In this aspect, it is expected that the crisis will negatively impact higher education. The austerity policy is expected to lead to less investment in higher education by the State. Moreover, families are expected to invest less in higher education of their younger members at every stage, from preparation for entrance, study, and graduation. 
However, a different perspective by Papastamou (2016) urges that the crisis is a challenge and an opportunity for improvement. Specifically, the crisis might serve as a stimulus for universities to develop into centers for dealing with various types of crises in general. Theoretically, this vision might serve as a reason for the State and families to invest in higher education. Skrbinjek et al. (2018) surveyed 29 European countries and concluded that the crisis had shrunk investment in higher education.

Research, by and large, confirms that the crisis in Greece has had a drastically negative impact on higher education (IOVE, 2017) and university life (Megaloeconomou, 2015; Tsikalaki \& Kladi-Kokkinou, 2016) due to the policy of reduced funding for higher education. More specifically, after a significant increase during 2001-2008, from 2009 until 2014, a 24\% reduction followed, which mostly affected expenses on students' meals, academics, and support personnel. Even though it is not higher than the reduction of funding for the rest of the public sector in Greece, it is higher than that in higher education in other European countries (IOVE, 2017).

Outcomes from research on student life and progress have given specific insights. On one hand, student enrollment increased, resulting in a higher student-toteacher ratio, which posed a challenge to teachers and reduced the number of enrolled students who did not complete studies (IOVE, 2017). Moreover, this increased social inequalities (Kazamias et al., 2002; Chrysochoou et al., 2013; Megaloeconomou, 2015; Tsikalaki \& Kladi-Kokkinou, 2016).

The impact of the universities' crisis can be examined by thoroughly investigating all its dimensions, including challenges for the academic community, impediments to academic careers, difficulties students encounter, and the State's general role (IOVE, 2017).

However, limited research has considered students' views on this topic, especially in the Greek context, which is the rationale for this research. Students "constitute the most central stakeholder group in higher education around the world" (Altbach et al., 2009, p. 97). Therefore, their opinions must be considered (Martin \& Sauvageot, 2011; UNESCO, 2009).

Bearing in mind the described research findings, it is expected that students would have experienced the side effects of the crisis in all the three dimensions, which means in the everyday life and expectations of their family, in the study conditions, as well as the future prospects and expectations (Altbach et al., 2009; Martin \& Sauvageot, 2011; UNESCO, 2009; Christopherson et al., 2014; Tsikalaki \& Kladi-Kokkinou, 2016; Azaria et al., 2020; Benham et al., 2020)

\section{Methodological Approach}

This research seeks to gain insights into students views' on the outcomes of the crisis in Greek higher education, focusing on three dimensions of its impact. The first concerns its impact on students' families. The second concerns its impact on student life in universities and the third on students' ambitions and visions about 
their career and life (Altbach et al., 2009; Chrysochoou et al., 2013; Christopherson et al., 2014; IOVE, 2017; Martin \& Sauvageot, 2011; UNESCO, 2009).

It was decided that a quantitative method focusing on descriptive statistics was the appropriate methodology for this research. The reason was that the research focuses on examining student's views that have not been thoroughly examined so far (Altbach et al., 2009; Azaria et al., 2020; Chryssochoou et al., 2013; Katsikas, 2013). It did not require studying inferential statistics and comparing values and parameters at that stage (Cohen et al., 2013). The data was collected through questionnaires. The questions were grouped under three categories; each category corresponded to one of the above dimensions. Every group included statements that addressed primary issues concerning the dimension revealed in the research and literature under study (IOVE, 2017). Participants were asked to rank each statement on a Likert scale, from 1 to 5 (1: Totally disagree, 2: Overall disagree, 3: Neither agree nor disagree, 4: Overall agree, and 5: Totally agree). The first and second dimensions were covered in 14 statements. Seven statements related to the third dimension.

The responses to the questionnaire were transferred to SPSS to be evaluated. The process included the absolute and relevant frequencies, calculated as a percentage of the total sample population. Along with it, the standard deviation was calculated. Due to the frequencies, it was possible to identify students' trends in thinking and overall opinion about the crisis' dimensions and side-effects (IOVE, 2017).

All the 300 students - 183 women (61\%) and 117 men (39\%)-included in the sample completed the questionnaires. The average age of the sample was 21.1. Of the sample, 237 (80.6\%) studied in the university while the remaining $57(19.4 \%)$ studied at higher technical institutes known in the Greek education system as TEI

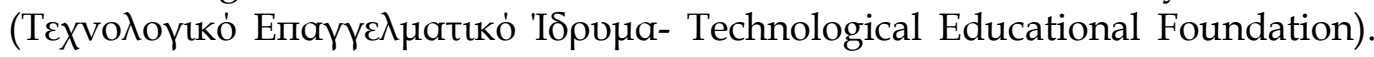
The sample was, therefore, representative, and hence, the findings may be accepted as accurate. Regarding ethics, the participants answered the questionnaire anonymously; the phrases included were stated in a way that did not cause any risk or adverse reaction to them (Cohen et al., 2013).

\section{Findings \& Principal Results}

As concluded by the findings, students express through their views that the crisis had a negative impact. This applies to all three dimensions, family environment, study conditions and prospects,

\section{Findings on the First Dimension: Crisis Impact on Social and Family Environment of Students}

From the data presented in Table 1, it becomes evident that students feel the crisis has affected their social and family environment in several ways. Regarding the adaptation to the crisis conditions, $76 \%$ of participants expressed they agree employees are reconciled to income decrease. This statement had an average score of 3.18 out of 5 on the Likert scale. Similarly, $77 \%$ of participants agreed totally or generally that people have resigned to the crisis (av. 3.93), and 93\% said that the crisis has permeated into everyday life (av. 4.17). 
On the question of whether the economic condition in Greece was reversible, 27\% expressed general or total agreement while $47 \%$ expressed general or total disagreement (av. 2.76). Moreover, 38\% agreed totally and 51\% disagreed totally (av. 3.03) with the statement that the crisis is temporary. With the statement that the economic conditions would worsen, $47 \%$ agreed while $21 \%$ disagreed (av. 3.38). Finally, the statement that crisis leads to immigration had an $82 \%$ express agreement (av. 4.35).

Table 1: Findings on the First Dimension: Crisis Impact on Social and Family Environment of Students

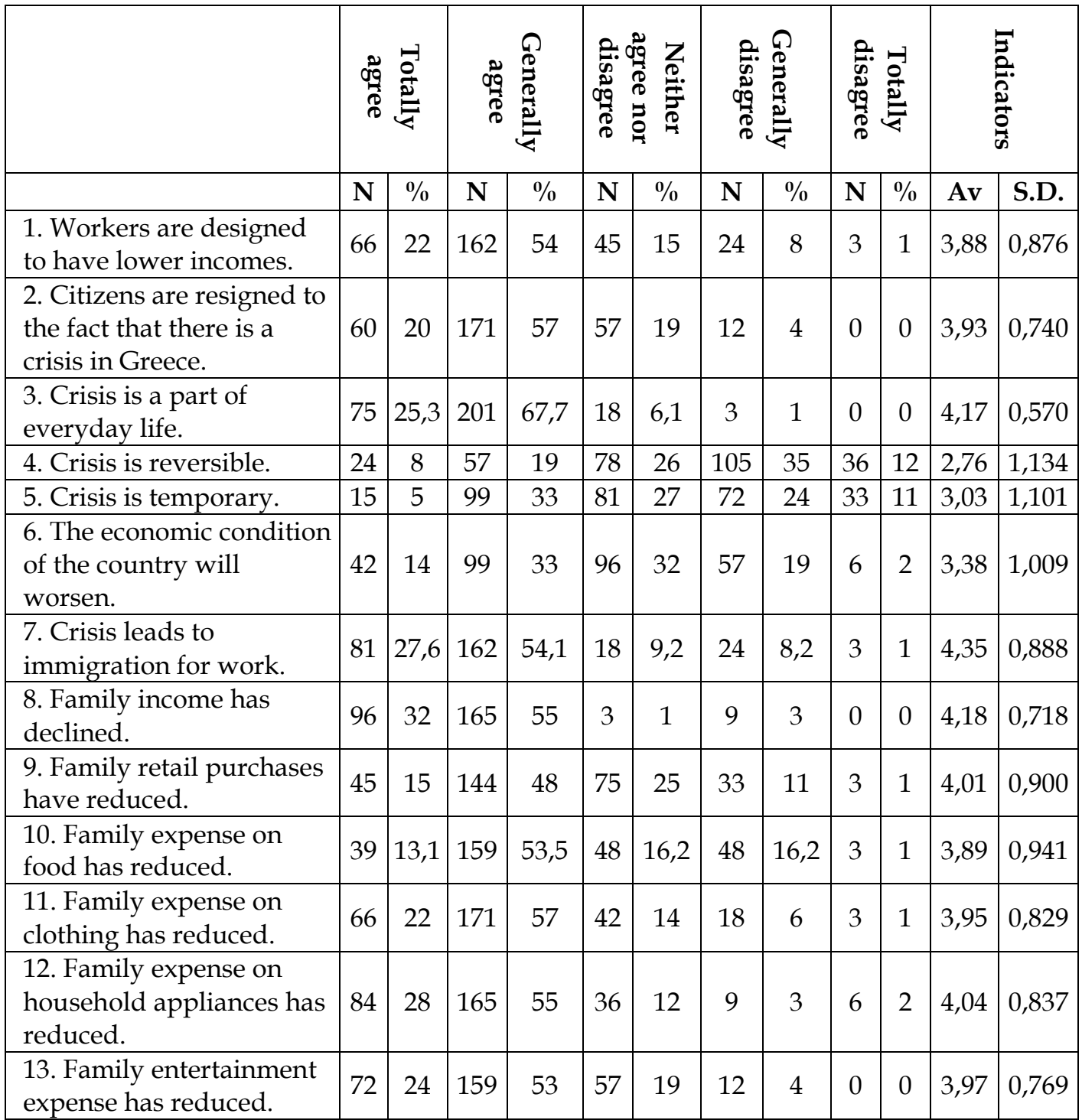

Regarding the impact of the family's crisis, $87 \%$ of the participants agreed that family income had declined (av. 4.18). Moreover, 63\% agreed that the consumption of goods had been restricted (a. 4.01). More specifically, the participants agreed that family expenses on goods of everyday use had shrunk: food $(67 \%$, av. 3.89), clothing (79\%, av. 3.95), household appliances (93\%, av. 4.04$)$, and leisure or entertainment (77\%, av. 3.97). Lastly, a substantial percentage (85\%, av. 4.22) agreed family members felt uncertain about the future. 
The above findings show that students believe the crisis had a substantial impact on their background, families, and environment and negatively affected their views of the future. However, being students, this did not deter them from getting a university education. The findings agree with those from such previous research that demonstrated a crisis causes families to find cost-effective solutions to enable their young members to go to university (Altbach et al., 2009; Christopherson et al., 2014; IOVE, 2017; Martin \& Sauvageot, 2011; UNESCO, 2009).

\section{Findings on the Second Dimension: Impact of Crisis on University Studies and Student Life}

Table 2 shows that students felt the crisis had affected their studies and life. Indicatively, on the effects of the crisis on universities, $78 \%$ agreed universities are affected (av. 3.98). Moreover, they agreed the crisis had caused a reduction in the university's resources, (82\%, av. 3.99), university personnel (86\%, av. 4.23$)$, and cultural courses, activities, and classes (75\%, av. 3.83). On the link between crisis and student life, $71 \%$ of the sample agreed there are effects (av. 3,9). More specifically, $91 \%$ agreed that parents had drastically reduced expenses on studies (av. 4.31). This relates to the agreement of $71 \%$ (av. 3.71) with the statement that the family has reduced expenditure on essential goods. Students tended to agree that the crisis has led to hesitation in buying essentials such as books $(55 \%$, av. $3.38)$, traveling while studying (51\%, av. 3.42), and participating in university activities (40\%, av. 3.08), including exchange programs such as Erasmus (59\%, av. 3.55).

Concerning dealing with the crisis, 82\% (av. 4.10) agreed that students were considering the crisis while deciding what to study, relating to the agreement (86\%, av. 4.21) that students prefer not to change location to avoid the extra expenses. Along with that, $76 \%$ (av. 3.92) agreed that house-sharing is an option to reduce expenses, $94 \%$ (av. 4.29) stated they worked while studying, even though $71 \%$ stated (av. 3.93) that working and studying at the same time is challenging. Lastly, 75\% (av. 3.98) stated that they interrupted studies for financial reasons and $43 \%$ (av. 2.91) stated their family required that every course was completed without delay. Findings drawn by students' views justify previous research outcomes that the crisis negatively impacts universities. The general trends adopted, either as policies or decisions, have been focused on cost-effective services in terms of personnel, infrastructure, and university functions. However, as students claim, at an individual or family level, there have been side-effects as well. Students tend to opt for more economical options concerning their studies. They try to reduce expenses whenever necessary. These attitudes and beliefs are commonly shared by the sample, as the values of average and standard deviation show. The primary conclusion drawn is that young people prefer making financial sacrifices and getting a university degree (Kazamias et al., 2002; Altbach et al., 2009; Christopherson et al., 2014; IOVE, 2017; Martin \& Sauvageot, 2011; UNESCO, 2009). 
Table 2: Impact of Crisis on Studies and Student Life

\begin{tabular}{|c|c|c|c|c|c|c|c|c|c|c|c|c|}
\hline & \multicolumn{2}{|c|}{ 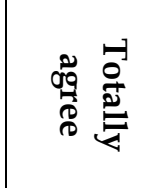 } & \multicolumn{2}{|c|}{ 象 } & \multicolumn{2}{|c|}{ 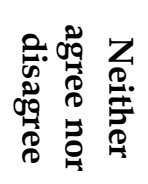 } & \multicolumn{2}{|c|}{ 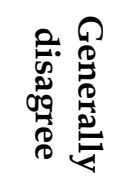 } & \multicolumn{2}{|c|}{  } & \multicolumn{2}{|c|}{ 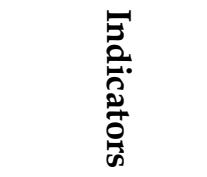 } \\
\hline & $\mathbf{N}$ & $\%$ & $\mathbf{N}$ & $\%$ & $\mathbf{N}$ & $\%$ & $\mathbf{N}$ & $\%$ & $\mathbf{N}$ & $\%$ & Av. & S.D. \\
\hline $\begin{array}{l}\text { 1. The financial crisis has } \\
\text { affected universities. }\end{array}$ & 87 & 29,3 & 144 & 48,5 & 42 & 14,1 & 21 & 7,1 & 3 & 1 & 3,98 & 0,900 \\
\hline $\begin{array}{l}\text { 2. University's resources } \\
\text { have reduced. }\end{array}$ & 81 & 27,3 & 162 & 54,5 & 33 & 11,1 & 12 & 4,3 & 9 & 3 & 3,99 & 0,906 \\
\hline $\begin{array}{l}\text { 3. University personnel } \\
\text { has reduced. }\end{array}$ & 123 & 41 & 135 & 45 & 30 & 10 & 12 & 4 & 0 & 0 & 4,23 & 0,787 \\
\hline $\begin{array}{l}\text { 4. University activities } \\
\text { have reduced. }\end{array}$ & 60 & 20,2 & 162 & 54,5 & 51 & 17,2 & 15 & 5,1 & 9 & 3 & 3,84 & 0,908 \\
\hline $\begin{array}{l}\text { 5. The crisis has affected } \\
\text { student life. }\end{array}$ & 87 & 29 & 126 & 42 & 60 & 20 & 24 & 8 & 3 & 1 & 3,90 & 0,945 \\
\hline $\begin{array}{l}\text { 6. Parents have reduced } \\
\text { expenses on education. }\end{array}$ & 123 & 41 & 150 & 50 & 24 & 8 & 3 & 1 & 0 & 0 & 4,31 & 0,660 \\
\hline $\begin{array}{l}\text { 7. Expenses on essential } \\
\text { goods have reduced. }\end{array}$ & 14 & 14 & 57 & 57 & 17 & 17 & 12 & 12 & 0 & 0 & 3,71 & 0,848 \\
\hline $\begin{array}{l}\text { 8. Expenses on study } \\
\text { material, books, pens, etc. } \\
\text { have reduced. }\end{array}$ & 39 & 13 & 126 & 42 & 51 & 17 & 78 & 26 & 6 & 2 & 3,38 & 1,067 \\
\hline $\begin{array}{l}\text { 9. Traveling while } \\
\text { studying has reduced }\end{array}$ & 51 & 17 & 102 & 34 & 72 & 24 & 72 & 24 & 3 & 1 & 3,42 & 1,062 \\
\hline $\begin{array}{l}\text { 10. Participation in } \\
\text { university activities has } \\
\text { reduced. }\end{array}$ & 30 & 10 & 90 & 30 & 75 & 25 & 84 & 28 & 21 & 7 & 3,08 & 1,122 \\
\hline $\begin{array}{l}\text { 11. Participation in } \\
\text { student exchange } \\
\text { opportunities (e.g., } \\
\text { Erasmus) has reduced }\end{array}$ & 51 & 17 & 126 & 42 & 72 & 24 & 39 & 13 & 12 & 4 & 3,55 & 1,045 \\
\hline $\begin{array}{l}\text { 12. Course selection has } \\
\text { been affected. }\end{array}$ & 90 & 30 & 156 & 52 & 48 & 16 & 6 & 2 & 0 & 0 & 4,10 & 0,729 \\
\hline $\begin{array}{l}\text { 13. Students avoid } \\
\text { relocating for studies. }\end{array}$ & 123 & 41 & 135 & 45 & 27 & 9 & 12 & 4 & 3 & 1 & 4,21 & 0,842 \\
\hline $\begin{array}{l}\text { 14. Home-sharing is opted } \\
\text { to reduce expenses. }\end{array}$ & 75 & 25 & 153 & 51 & 51 & 17 & 15 & 5 & 6 & 2 & 3,92 & 0,892 \\
\hline $\begin{array}{l}\text { 15. Students tend to work } \\
\text { while studying. } \\
\end{array}$ & 114 & 38 & 168 & 56 & 12 & 4 & 3 & 1 & 3 & 1 & 4,29 & 0,684 \\
\hline $\begin{array}{l}16 . \text { Working while } \\
\text { studying is challenging. }\end{array}$ & 102 & 34 & 111 & 37 & 57 & 19 & 21 & 7 & 9 & 3 & 3,92 & 1,038 \\
\hline $\begin{array}{l}\text { 17. Students have } \\
\text { interrupted studies due to } \\
\text { financial restrictions. }\end{array}$ & 87 & 29 & 138 & 46 & 57 & 19 & 18 & 6 & 0 & 0 & 3,98 & 0,850 \\
\hline $\begin{array}{l}\text { 18. Families press for on- } \\
\text { time studies' } \\
\text { accomplishment. }\end{array}$ & 27 & 9 & 87 & 29 & 54 & 18 & 96 & 32 & 36 & 12 & 2,91 & 1,203 \\
\hline
\end{tabular}


Findings on the Third Dimension: Crisis Impact on Students' Expectations As seen in Table 3, there is general agreement that the crisis has affected students' expectations. Indicatively, $56 \%$ (av. 3.48) believes that a higher number of qualifications increases the possibilities for excellent job opportunities. Simultaneously, $74 \%$ (av. 3.88) of the population agreed there is pessimism toward their professional future while 73\% (av. 3.99) agreed the crisis affects their work decisions. Moreover, there is agreement at $60 \%$ (av. 3.54) that a university degree is not sufficient for the labor market that applies more, particularly when it comes to university degrees from Greece (43.5\%, av. 3.3). Along with that, $51.5 \%$ (av. 3.44) agreed post-graduate studies could help during a crisis, whereas $73 \%$ (av. 3.93) considered moving to another country.

Overall, students' expectations are influenced by the crisis, as the literature has stated. This is seen through their statements that they are not so optimistic about overcoming crises and their working opportunities. They also agree that an undergraduate degree does not guarantee a successful career by itself. However, they still consider it necessary. Moreover, they hold the opinion that, generally, higher education institutions and universities can provide qualifications that assist in the future career, whether post-graduate studies or any other option. Finally, they identify that the trend of mobility exists since they are willing to relocate for a career (Altbach et al., 2009; Christopherson et al., 2014; IOVE, 2017; Martin \& Sauvageot, 2011; UNESCO, 2009).

Table 3: Impact of Crisis on Students' Expectations

\begin{tabular}{|c|c|c|c|c|c|c|c|c|c|c|c|c|}
\hline & \multicolumn{2}{|c|}{ 总定 } & \multicolumn{2}{|c|}{ 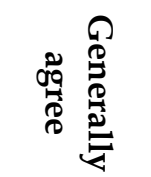 } & \multicolumn{2}{|c|}{ 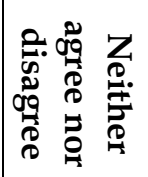 } & \multicolumn{2}{|c|}{ 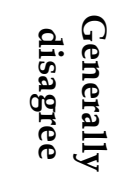 } & \multicolumn{2}{|c|}{ 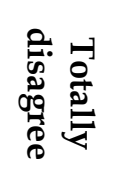 } & \multicolumn{2}{|c|}{$\begin{array}{l}5 \\
\vdots \\
0 \\
0 \\
0 \\
0\end{array}$} \\
\hline & $\mathbf{N}$ & $\%$ & $\mathbf{N}$ & $\%$ & $\mathbf{N}$ & $\%$ & $\mathbf{N}$ & $\%$ & $\mathbf{N}$ & $\%$ & Av. & S.D. \\
\hline $\begin{array}{l}\text { 1. Qualifications increase job } \\
\text { opportunities. }\end{array}$ & 30 & 10,1 & 135 & 45,5 & 90 & 30,3 & 33 & 11,1 & 9 & 3 & 3,48 & 0,927 \\
\hline $\begin{array}{l}\text { 2. Students are pessimistic } \\
\text { toward professional career } \\
\text { opportunities. }\end{array}$ & 75 & 25,3 & 144 & 48,5 & 51 & 17,2 & 21 & 7,1 & 6 & 2 & 3,88 & 0,937 \\
\hline $\begin{array}{l}\text { 3. The crisis influences } \\
\text { students' decisions on work. }\end{array}$ & 78 & 26,3 & 138 & 46,5 & 69 & 23,2 & 6 & 2 & 6 & 2 & 3,93 & 0,869 \\
\hline $\begin{array}{l}\text { 4. The degree is not } \\
\text { sufficient for the labor } \\
\text { market. }\end{array}$ & 51 & 17,2 & 126 & 42,4 & 87 & 29,2 & 51 & 17,2 & 9 & 3 & 3,54 & 1,059 \\
\hline $\begin{array}{l}\text { 5. University studies in } \\
\text { Greece do not suffice for } \\
\text { excellent job opportunities. }\end{array}$ & 45 & 15,2 & 84 & 28,3 & 108 & 36,4 & 39 & 13,1 & 21 & 7,1 & 3,31 & 1,100 \\
\hline $\begin{array}{l}\text { 6. Students select } \\
\text { postgraduate studies as a } \\
\text { means against the crisis. }\end{array}$ & 36 & 12,1 & 117 & 39,4 & 102 & 34,3 & 27 & 9,1 & 15 & 5,1 & 3,44 & 0,989 \\
\hline $\begin{array}{l}\text { 7. Students consider moving } \\
\text { abroad because of the crisis. }\end{array}$ & 84 & 28,0 & 135 & 45,4 & 16 & 16,5 & 24 & 8,2 & 3 & 1 & 3,93 & 0,935 \\
\hline
\end{tabular}




\section{Conclusions}

This research aimed to identify the impact of the economic crisis on students' life in Greece through the prism of socio-economic background, studying conditions, and aspirations for the future. The crisis can have a three-dimensional impact on students' lives, as it can influence their family and social background, the conditions of studies and student life, and their expectations and personal perspectives. Research conducted around this topic so far does not seem to emphasize the views of students. This is the main contribution of this research. Bearing in mind the literature around crisis and universities, it would be expected that students would experience and express the opinion that the crisis had a significant negative impact on all three dimensions (Altbach et al., 2009; Azaria et al., 2020; Chryssochoou et al., 2013; Katsikas, 2013).

The findings reveal that participants believe the crisis is a long-lasting phenomenon with significant effects, not easily reversible. It is generally accepted that immigration for financial reasons is inevitable. Especially in what concerns family, participants agree that most families have reduced income, consumption, or spending. This has caused cuts in expenses on household appliances, clothes, entertainment, and other basics. These findings are compatible with research outcomes (Altbach et al., 2009; Christopherson et al., 2014; Sointu et al., 2019).

Regarding university studies, participants said the crisis has affected the quality of studies, mainly because of the reduction in funding and families' efforts to reduce expenses. This motivates students to reduce expenses on travel, stationery, and other basic needs. The crisis has affected subjects' choice to study, and preference is now given to subjects that lead to better, more secure, and easier-tofind career opportunities, especially near their homes. This indicates a lack of confidence in future career opportunities and the value of the university degree, leading them to seek further education to qualify for work in a competitive labor market (Altbach et al., 2009; Christopherson et al., 2014; IOVE, 2017; Martin \& Sauvageot, 2011; UNESCO, 2009).

Therefore, the findings confirm that students claim to have been affected deeply by the crisis (Altbach et al., 2009; Azaria et al., 2020; Katsikas, 2013). Before generalizing these conclusions, it is essential to stress the limitations of the particular study. A first limitation has to do with the specific sample that was gathered in a certain period. Perhaps, in the future, benchmarking with broader samples and more full dimensions of the crisis will strengthen the accuracy of these conclusions (Cohen et al., 2013).

\section{References}

Altbach, P. G., Reisberg, L., \& Rumbley, L. E. (2009). Trends in global higher education: Tracking an academic revolution. SIDA/SAREC.

Altundemir, M. E. (2012). The impact of the financial crisis on American public universities. International Journal of Business and Social Science, 3(8), 190-198.

Azaria, A., Karavasilis, G., Kehris, E., \& Vrana, V. (2020). The impact of the financial crisis on university students in Greece. South-Eastern Europe Journal of Economics, 17(2), 193-219. 
Becker, G. (1993). Human capital: A theoretical and empirical analysis, with special reference to education (3rd ed.). The University of Chicago Press.

Behnam, B., Paknazar, F., Mirmohammadkhani, M., Akhbari, M., Hoseini, S. M., \& Sabahi, P. (2020). Personal, familial and social factors associated with academic failure in university students: A case-control study in Iran. International Journal of Learning, Teaching and Educational Research, 19(3), 36-47. https://doi.org/10.26803/ijlter.19.3.3

Berry, S. (2002). Does education matter? Myths about education and economic growth, by Alison Wolf. A book review. The Economics of Education. Retrieved from http://www.laarticles.org.uk/eoe.htm

Christopherson, S., Gertler, M., \& Gray, M. (2014). Universities in crisis. Cambridge Journal of Regions, Economy and Society, 7(2), 209-215. https://doi.org/10.1093/cjres/rsu006

Chryssochoou, X., Papastamou, S., \& Prodromitis, G. (2013). Facing the economic crisis in Greece: The effects of grievances, real and perceived vulnerability, and emotions towards the crisis on reactions to austerity measures. JSSE - Journal of Social Science Education, 1-2013: Youth Civic \& Political Participation \& Citizenship Education in the Mediterranean: Lessons from the Arab Spring. https://doi.org/10.4119/JSSE-633

Cohen, L., Manion, L., \& Morrison, K. (2013). Research methods in education (7th ed.). Routledge.

Coleman, R., \& Bekhradnia, B. (2014). Higher education supply and demand to 2020. HEPI. Retrieved from http://www.hepi.ac.uk/wp-content/uploads/2014/02/1.2010demand-report-master.pdf

Daim, T. U., \& Ozdemir, D. (2015). Impact of US economic crises on university research and development investments. Journal of the Knowledge Economy, 6(1), 13-27. https://doi.org/10.1007/s13132-012-0135-2

EUA. (2011). Impact of the economic crisis on European universities. Retrieved from https:// eua.eu/downloads/publications/impact $\% 20$ of $\% 20$ the $\% 20$ economic $\% 20$ crisis\%20on\%20uropean\%20universities\%20january\%202011.pdf

Fragoudaki, A. (1985). Educational sociology. Theories of social inequality in school. Papazisis Publications.

Fullan, M. (2001). The new meaning of educational change (3rd ed.). Teacher's College Press.

Gouvias, D. (2012). Accountability in the Greek higher education system as a high-stake policymaking instrument. Higher Education Policy, 25(1), 65-86. https://doi.org/10.1057/hep.2011.23

Hasanen, K. (2020). "Glocal" transnational higher education: A case study of a FinnishVietnamese collaboration. International Journal of Learning, Teaching and Educational Research, 19(2), 305-317. https:/ / doi.org/10.26803/ijlter.19.2.19

IOVE. (2017). Higher education in Greece. Challenges and side-effects of the crisis. Retrieved from http://iobe.gr/docs/research/RES_05_F_05072017_REP_GR.pdf

Katsikas, E., (2013). The impact of students' working status on academic progress: Assessing the implications of policy change in Greece. Journal of Education and Work, 26(5), 539-569. https://doi.org/10.1080/13639080.2012.691606

Kazamias, A., Zambeta, E., \& Karadjia, E. (2002). Greece: Educational Reform 2000 Toward a Paideia of open orizons - The modern Greek Sisyphus. In S. Linblad \& T. S. Popkewitz (Eds.), Education governance and social integration and exclusion: Studies in the powers of reason and the reasons of power (pp. 165-203). Uppsala Reports on Education 39, Uppsala University.

Martin, M., \& Sauvageot, C. (2011). Constructing an indicator system or scorecard for higher education. A practical guide. UNESCO. Retrieved from http://uis.unesco.org/sites/default/files/documents/constructing-an- 
indicator-system-or-scorecard-for-higher-education-a-practical-guide-2011en.pdf

Megaloeconomou, R. (2015, August 4). How the economic crisis is affecting higher education in Greece. World Economic Forum. Retrieved from https://www.weforum.org/agenda/2015/08/how-the-economic-crisis-isaffecting-higher-education-in-greece/

Oxford University. (2015). International trends in higher education 2015. Retrieved from https://www.ox.ac.uk/sites/files/oxford/International\%20Trends\%20in $\% 20 \mathrm{Hi}$ gher\%20Education\%202015.pdf

Papastamou, A. (2016). Universities against the international crisis. Science and Society: Review of Political and Ethical Theory, 23, 155. https://doi.org/10.12681/sas.10327

Pesmatzoglou, S. (1989). Education and development in Greece 1948-1985. The inconsistency of a relationship. Themelio.

Petmezidou-Tsoulouvi, M. (1987). Social classes and social reproduction mechanics. Sextant.

Sianou-Kyrgiou, E. (2010). Stratification in higher education, choice and social inequalities in Greece. Higher Education Quarterly, 64(1), 22-40. https://doi.org/10.1111/j.1468-2273.2009.00427.x

Sklavos, D. (2015). The impact of economic crisis and formal education in Greece. Economic crisis and formal education in Greece (2015-02-05) [Master's Thesis, University of Patras]. NEMERTES Database. Retrieved from http://hdl.handle.net/10889/8296

Skrbinjek, V., Šušteršič, J., \& Lesjak, D. (2018). Political preferences and public funding of tertiary education during the economic crisis. Tertiary Education and Management, 24(2), 168-186. https://doi.org/10.1080/13583883.2017.1407958

Sointu, E., Hirsto, L., \& Murtonen, M. (2019). Editorial transforming higher education teaching and learning environments - Introduction to the special issue. International Journal of Learning, Teaching and Educational Research, 18(13), 1-6. https://doi.org/10.26803/ijlter.18.13.1

Tsikalaki, I., \& Kladi-Kokkinou, M. (2016). Economic crisis and social inequalities in education: Candidates' educational choices for higher education. Academia - A publication of the Higher Education Policy Network, 7, 34-82. Retrieved from https://academia.lis.upatras.gr/academia/article/view/2704/2963

UNESCO. (2009). Global Education Digest 2009. Comparing education statistics across the world. UNESCO Institute of Statistics. Retrieved from http:/ / uis.unesco.org/sites/default/files/documents/global-education-digest2009-comparing-education-statistics-across-the-world-en_0.pdf

Wolf, A. (2002). Does education matter? Myths about education and economic growth. Penguin Books Limited. 